\title{
Structural Style in the Khalfani Anticline, Coastal Fars, Zagros Fold-Thrust Belt
}

\author{
Arezo Baghbanan1, Zahra Maleki ${ }^{*}$, Mohsen Pourkemani ${ }^{2}$ \\ ${ }^{1}$ Department of Geology, Science and Research Branch, Islamic Azad University, Tehran, Iran \\ ${ }^{2}$ Department of Geology, Faculty of Basic Sciences, Islamic Azad University, North Tehran Branch, \\ Tehran, Iran \\ Email: ${ }^{*}$ z.maleki@srbiau.ac.ir
}

Received 8 May 2015; accepted 26 September 2015; published 29 September 2015

Copyright (C) 2015 by authors and Scientific Research Publishing Inc.

This work is licensed under the Creative Commons Attribution International License (CC BY). http://creativecommons.org/licenses/by/4.0/

(c) () Open Access

\section{Abstract}

The Khalfani anticline is located in the Coastal Fars (Zagros, adjacent Persian Gulf). This anticline with Northwest-Southeast trend is a fault bend fold. In the study area, the Khalfani anticline has increased elevation from West to East with three distinct humps. The major faults in the study area are the Hendurabi and the Razak sinistral strike slip faults. Because analysis of fold and their folding styles in different parts system is important, the analysis of folding style elements is necessary for structural studies. The main aim of this research is structural style analysis based on fold style elements in the Khalfani anticline. This analysis is important for progress in hydrocarbons exploration in the Coastal Fars area. In this research, we used Tectonics FP and Global Mapper Software for preparing some data in our study. In addition, we used the common classification of folds for our research. Based on given results, the folding pattern of this anticline has indicated that the fold style is same in different parts of the Khalfani anticline. In the study area, based on classifications of fold in different methods, fold style is same together. Fold, with close sideways requires special attention as structural view; then the Khalfani Anticline with close style in all parts has special deformation and folding style. It seems that in the study area, folding style and variation of structural style have been created by effect of the Razak and the Hendurabi sinistral strike slip fault. Because these faults are basement or deep-seated faults, special folding style and special deformation can be formed in the study area. In addition, the Khalfani anticline in the study area has restricted within the Razak and the Hendurabi sinistral strike slip faults.

\section{Keywords}

Khalfani Anticline, Structural Style, Hendurabi and Razak Faults

\footnotetext{
*Corresponding author.
} 


\section{Introduction}

The Zagros foreland basin was produced by construction of the Zagros fold-thrust belt during the Arabia-Eurasia collision [1]-[3]. This fold-thrust belt consists of a hinterland zone of emergent SW-directed thrust faults near the suture (High Zagros and "Crush Zone”) [4] and a frontal belt of large, regularly spaced, NW-trending folds with few exposed thrusts (Simply Folded Zone) [4]-[10].

Active deformation in the Zagros is caused by the northward motion of Arabia with respect to Eurasia, which occurs at a rate of $25 \mathrm{~mm} /$ year at longitude $561 \mathrm{E}$ [11]-[14]. The deformation in this part of the belt is characterized by periodic folding with axial lengths sometimes greater than $200 \mathrm{~km}$.

The study area (Figure 1) is located in the Zagros simply folded belt of Iran and in the Coastal Fars sub-basin [15]. The Simply Folded Zone (SFZ) is orientation as southwestern boundary of the Zagros orogen near the Persian Gulf. In this region, the folds are capped by the Oligocene Asmari Limestone [16]-[18] and the sedimentary cover sequence is floored by the Hormuz Formation, a dominantly evaporate formation, which acts as a major decollement horizon [19]-[21].

In this area, the Khalfani anticline has asymmetric structure and some faults such as the Nezamabad fault effect on this anticline (Figure 2, Figure 3). This structure is located in the Coastal Fars area (adjacent Persian Gulf). The Fars province is located to the Southeast of the Zagros fold belt. The deformation in this part of the belt is characterized by periodic folding with axial lengths sometimes greater than $200 \mathrm{~km}$ (Figure 3 ). The geometry of anticlines in the Zagros fold-thrust belt is affected by the type of deformation and mechanical behavior of stratigraphic units specially detachment units [22]. In this belt, detachment units are important

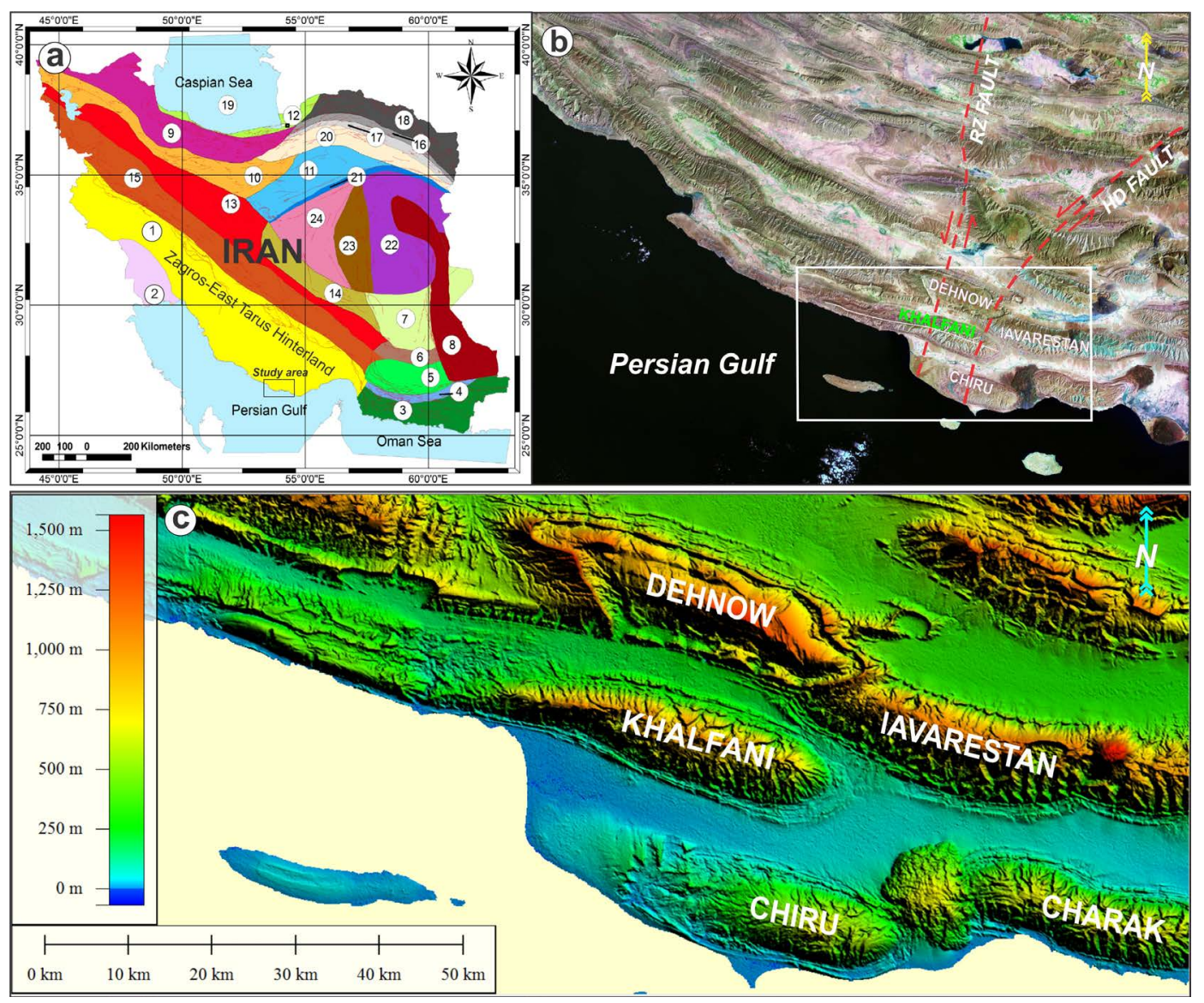

Figure 1. (a) This map showslocation of the study area (black rectangular) in the physiographic-tectonic zoning map of Iran's sedimentary basin [26]; (b) Landsat Satellite image shows the study area and location of the Khalfani anticline in the Zagros fold-thrust belt, southern of Iran (white framework). Inset Satellite image also, in this figure shows location of the Khalfani salt plug in the studyarea; (c) SRTM image of the study area shows the Khalfani Anticline and their adjacent anticlines in the Coastal Fars. 


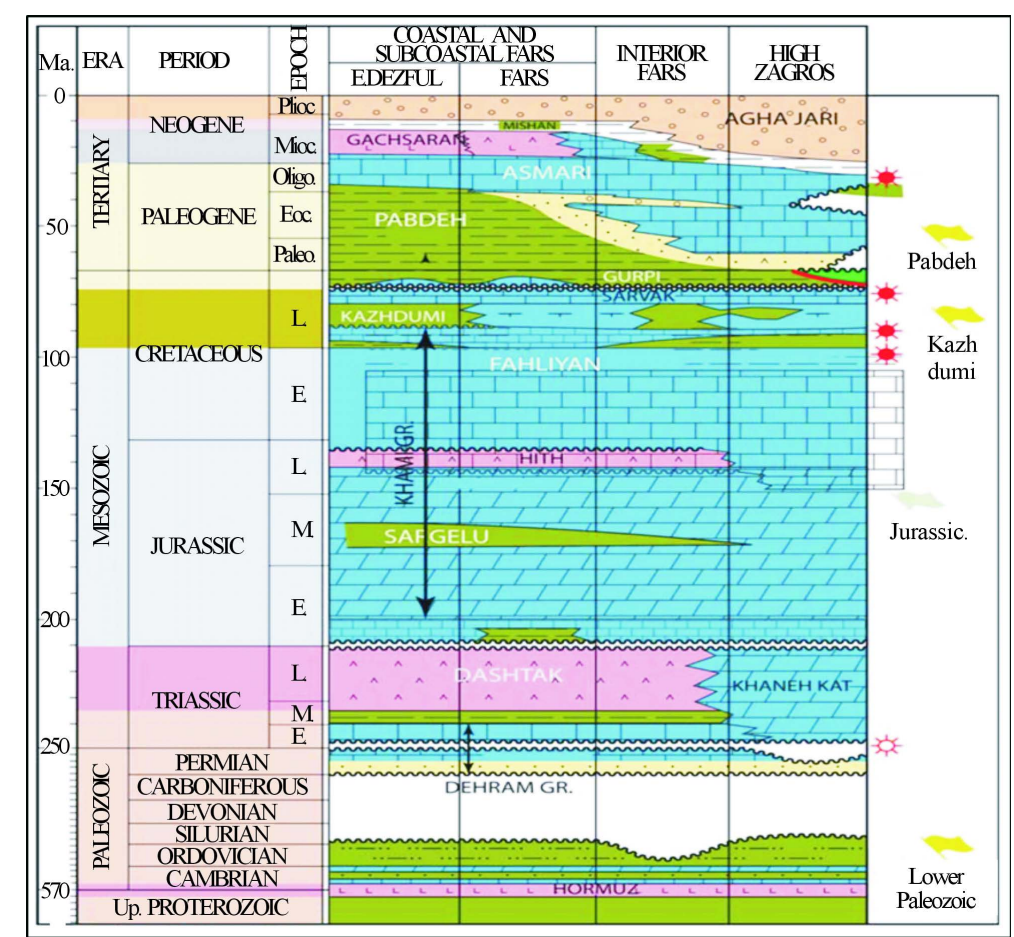

Figure 2. Simplified stratigraphicchart [37], indicating the petroleumsystems. Source: rocks areindicated with green shadowing, reservoirs with blueshadowing and seals with pinkshadowing (modified after [38]).

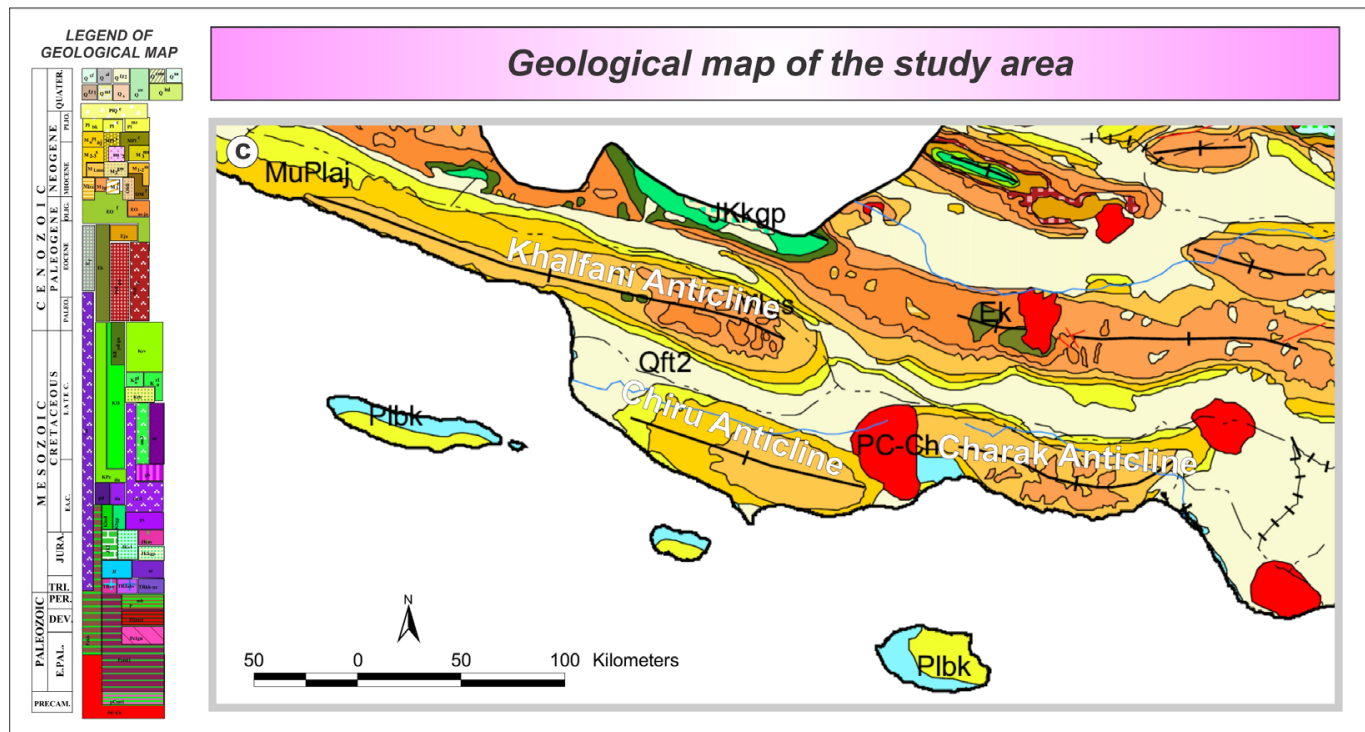

Figure 3. Geological map of the study area (modified after geological survey of Iran on the geological map of the Hormozgan area). This map shows the location of the Khalfani anticline.

for controlled folding pattern [23] [24]. The basal Hormuz and other detachments play important roles for the style of the Zagros Fold-thrust belt structures. One of the main detachment units in the study area is the Dashtak formation that belongs to the Kazeron group. This formation is composed of evaporate, shale and dolomite units.

In the Zagros fold-thrust belt, structural analysis of surface and subsurface data shows that salt layers such as Cambrian Hormuz and the Miocene Gachsaran have direct control on the structural style [25]. Until now, In the 
Zagros fold-thrust belt, many studies have been done on the variation of structural style and effects of detachment folding on folding pattern [23]-[27]. Also, many researchers discussed basement involvement and reactivated structures in the Zagros fold-thrust belt and its roll on folding pattern, e.g. [29]-[33].

For the first time, O’Brien (1950) [34] introduced concept of mechanical lithology in this area and for the first time showed the effects of detachment layers on folding process. In addition, other researchers have discussed about this case too, e.g. [19] [23] [25]-[29].

The limestones beds of the Asmari Formation outline the fold geometry in the Fars province, which is one of the main oil reservoirs in the Zagros [8]. In this area, the low topography and the lack of clear fold vergence were considered characteristic of a thin-skinned fold-thrust belt controlled by the extreme weakness of the salt at its base [35]. The Khalfani anticline has northwest-southeast trend and this anticline is located in the Coastal Fars (Zagros, adjacent Persian Gulf). In the study area, the Khalfani anticline has increased elevation from west to east with three distinct humps. The major faults in the study area are the Hendurabi and the Razak sinistral strike slip faults.

Description of fold geometry is important because they allow comparisons within and between folds and pattern-recognition in addition to occurrence and distribution of fold systems. The main aim of this research is structural style analysis based on fold style elements in the Khalfani anticline. This analysis is important for progress in hydrocarbons exploration in the Coastal Fars area.

\section{Material and Methods}

This paper presents part of the results of a regional study of the Coastal Farsarea in the Zagros Simply folded belt, based on original fieldwork, satellite images, structural sections, geological maps and well data. We used fold style elements analysis methods (description of folds) based on [39]-[42]. We used Tectonics FP software for prepared and analyzed stereo plots of the Khalfani anticline. In addition, we used Global Mapper Software for prepared 3D SRTM of the study area and 3D Path Profile (along cross sections) based on Global Mapper Software. 3D SRTM prepared based on Digital Elevation Model (DEM) and geological map of study area (published by the National Oil Company and the Geological Survey of Iran).

\section{Geological Setting and Stratigraphy}

In the Zagros fold-thrust belt, the Fars geological province, based on geological fancies units perpendicular to Zagros belt was divided into the Interior Fars, Sub-Coastal and Coastal Fars sub-basins [15] and the study area is located in the Coastal Fars sub-basin. This area is easily recognized by the NW-SE orientation parallel anticlines that verge to the SW in a 6 - $12 \mathrm{~km}$ cover sequence [43]-[46].

In the Zagros fold-trust belt, the oldest known stratigraphic unit with 2000 - 1000 meters thickness estimated as Hormuz Series [47] [48] and is exposed in the form of salt domes in the Coastal Fars region. The oldest stratigraphy unit that outcropped in Western Part of the Charak anticline (Figure 3) near the Khalfani anticline belongs to Hormuz Series (salt plug). The age of Hormuz Series is Pre-Cambrian-Cambrian. Anticlines outcropping stratigraphic units in the most of structures Coastal Fars region often include Upper Cretaceous stratigraphic units (Maestrichtian-Campanian to the present) and in the sub-coastal region, includes the Lower Cretaceous stratigraphic units (Neocomian to the present).

The Khalfani anticline is located in the Parsian area of the Hormozgan province (adjacent Persian Gulf). This anticline has Northeast-Southeast trend. This anticline is bounded from Northeast by the Dehnow anticline, from southeast by the Chiru anticline and from West-Southwest by the Tabnak anticline and Persian Gulf (Figure 1).

The Khalfani anticline is an asymmetric structure, which has $45 \mathrm{~km}$ length and $4-12 \mathrm{~km}$ width on the surface (Figure 1, Figure 3). Based on Setchell et al. (2007), the Khalfani anticline is a fault bend fold. This anticline is an asymmetrical anticline in which the dip of southern flank is greater than the northern flank (Figure 6 and Figure 7). On the other hand, plunges dip value in western part of anticline more than eastern part.

\section{The Description of Folds}

Description of fold geometry is important because they allow comparisons within and between folds and allow us to recognize patterns in the occurrence and distribution of fold systems. For example, orogenic belts contain characteristic fold systems: along their flanks are large fold and thrust belts, with little metamorphism, but underlain by décollements; and in core zones where intense folding has accomplished, accompanied by high-grade 
metamorphism under high temperature and pressure. In the thrust-fold regions located parallel to orogenic belts, certain characteristic types of folds tend to develop; the folds themselves are usually cylindrical with horizontal hinges and are composed of largely unmetamorphosed rock. In the foreland, folds tend to be upright and open, while in the hinterland they tend to be isoclinal and inclined/recumbent, with vergence toward the hinterland. At depth, these folds tend to die out at décollements and may be associated with fault-ramp folds, especially toward the foreland [30].

\section{Elements of Fold Style}

The style of a fold is the set of characteristic that describe its form. Over years of working with folds, geologists have identified certain features as particularly useful in describing fold and understanding how they develop [42].

Because the Khalfani anticline, has unique structure; the analysis of fold style elements is seems necessary. Therefore, for more studies on this structure the changes of fold style elements will be analyzed and investigated from east to west in the different parts of this anticline. Because of the Nezamabad fault effect on the middle parts of the Khalfani anticline, we have evaluated and calculated some elements of fold style, measurable in this structure. In this respect, symmetry, cylindricity, geometry of axial plane and folding mechanism has evaluated.

\subsection{Symmetry}

A folded surface forms a symmetric fold if in profile, the shape on one side of the hinge is a mirror image of the shape on the other side, and if adjacent limbs are identifiable in length [36]. The study anticline is an asymmetric fold with changed plunge in the north of the western part of fold. The Khalfani anticline is an asymmetric anticline. In the southern flank, dip of layers is greater than the northern flank. In this anticline, Southern flank, layers have dip changes from about $54^{\circ}$ to $70^{\circ}$ and dip value in northern flank ranges about $52^{\circ}$ to $60^{\circ}$.

\subsection{Cylindricity}

The cylindricity is represented qualitatively on a stereonet by how closely the poles to planes around a fold fit a great circle distribution [36]. The studied anticline is a cylindrical to conical fold with changed plunge in the north of the western part of fold. The output of Tectonics FP software for five parts of the Khalfani anticline is shown in the Figure 4.

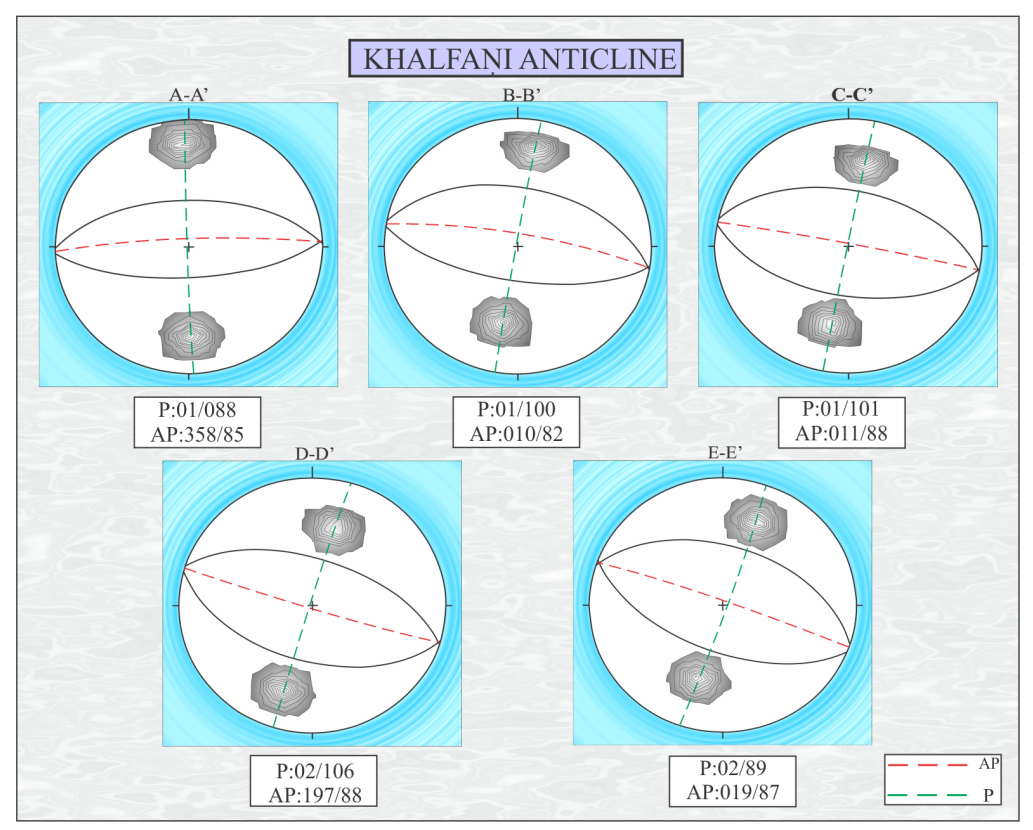

Figure 4. Stereoplots show axial planes (AP), cylindricity (AC) and plunge of fold (P) for five sections of the Khalfani anticline (based on [39]). 


\section{Classification of the Fold}

Based on Twiss and Moors method (1992) for description of fold, stereoplots (output of Tectonics FP software) were prepared for five parts of the Khalfani anticline. According to results, stereoplots show the location of axial plane (AP) and cylindricity (AC) and Plunge of Fold (P) (Figure 4). This part to be done based on five structural cross sections of the Khalfani anticline. The locations of these structural cross sections (from A-A' to G-G') is shown in the Figure 4. In this part of the Khalfani anticline, based on the classification Rickard (1971) [22], type of fold in all sections is Upright horizontal. In A-A' section, fold axis characteristic is (P) 01/088 and the axial plane (AP) is 358/85 (in this part characteristic of elements of fold style is based on dip and dip direction). According to the classification Twiss and Moors (1992) [39] for classification of folds based on the angle between the interlimb and folding angles, fold type in A-A' section is close fold. The dip average on the southern flank is 70 degree and dip value in northern flank is about 60 degree.

In B-B' section, fold axis characteristic is (P) 01/100 and the axial plane (AP) is 010/82. According to the classification Twiss and Moors (1992) [39] for classification of folds based on the angle between the interlimb and folding angles, fold type in B-B' section is close fold. The dip average on the southern flank is 68 degree and in northern flank is about 52 degree. In C-C' section, fold axis characteristic is (P) 01/101 and the axial plane (AP) is 011/88. According to the classification Twiss and Moors (1992) [39] for classification of folds based on the angle between the interlimb and folding angles, fold type in C-C' section is close fold. The dip average on the southern flank is 58 degree and dip value in northern flank is about 54degree.

In D-D' section, fold axis characteristic is (P) 02/106 and the axial plane (AP) is 197/88. According to the classification Twiss and Moors (1992) [39] for classification of folds based on the angle between the interlimb and folding angles, fold type in D-D' section is close fold. The dip average on the southern flank is 54 degree and in northern flank is about 60 degree. In E-E' section, fold axis characteristic is (P) 02/89 and the axial plane (AP) is 019/89. According to the classification Twiss and Moors (1992) [39] for classification of folds based on the angle between the interlimb and folding angles, fold type in E-E' section is close fold. The dip average on the southern flank is 60 degree and in northern flank is about 52 degree.

\section{Based on Folding Mechanism and Fold Orientation}

In this part, based on classification of Rickard (1971) [41] and Ragan (2009) [42], in the different parts of the Khalfani anticline, type of fold is same together and one types are recognize (Figure 5 and Figure 6). In all of the parts of the Khalfani anticline, type of fold is upright fold. Also based on classification of Ramsay (1967) [40], in the entire parts of this anticline, axial plane is sub-horizontal.

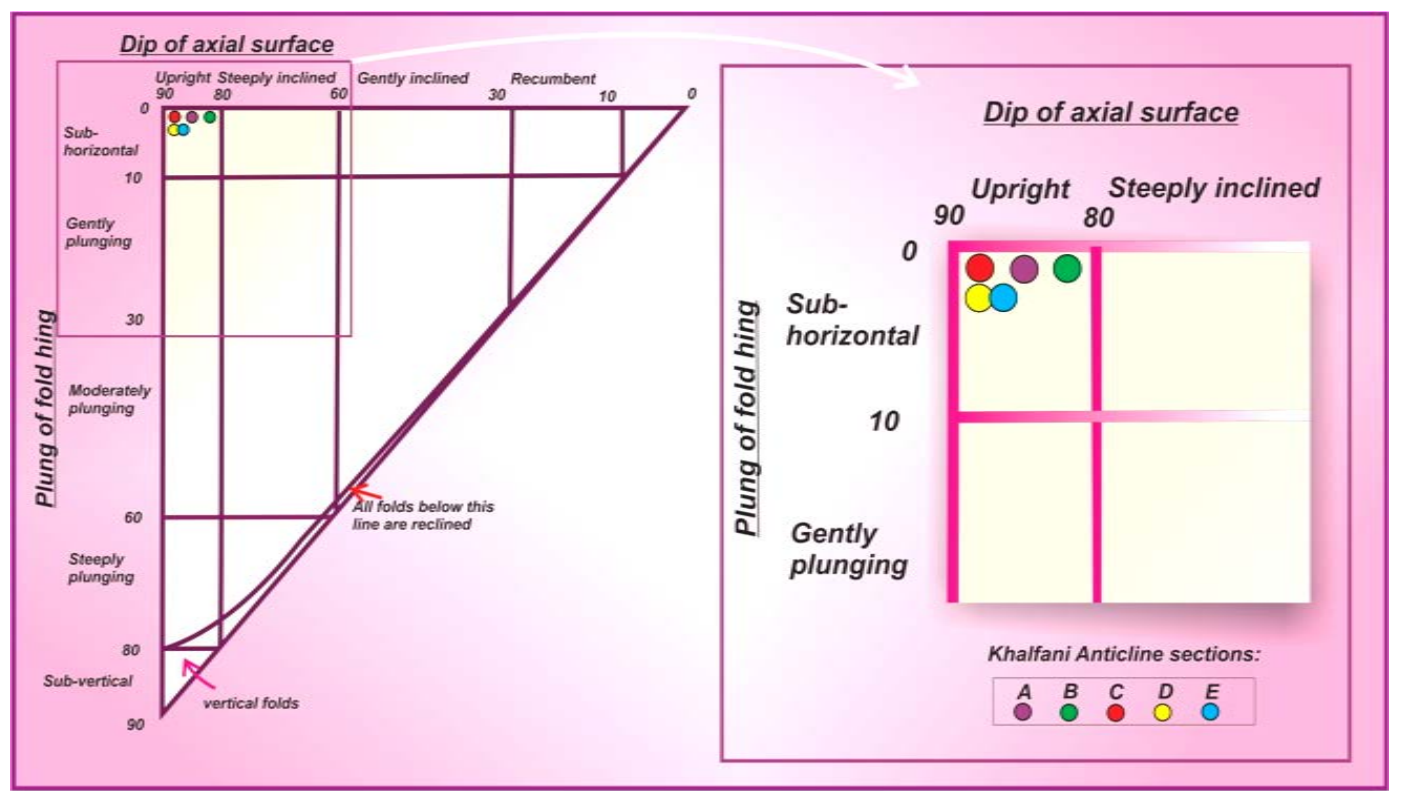

Figure 5. This figure shows the classification for orientation of the Kuh-e Qazi anticline based on [42]. 


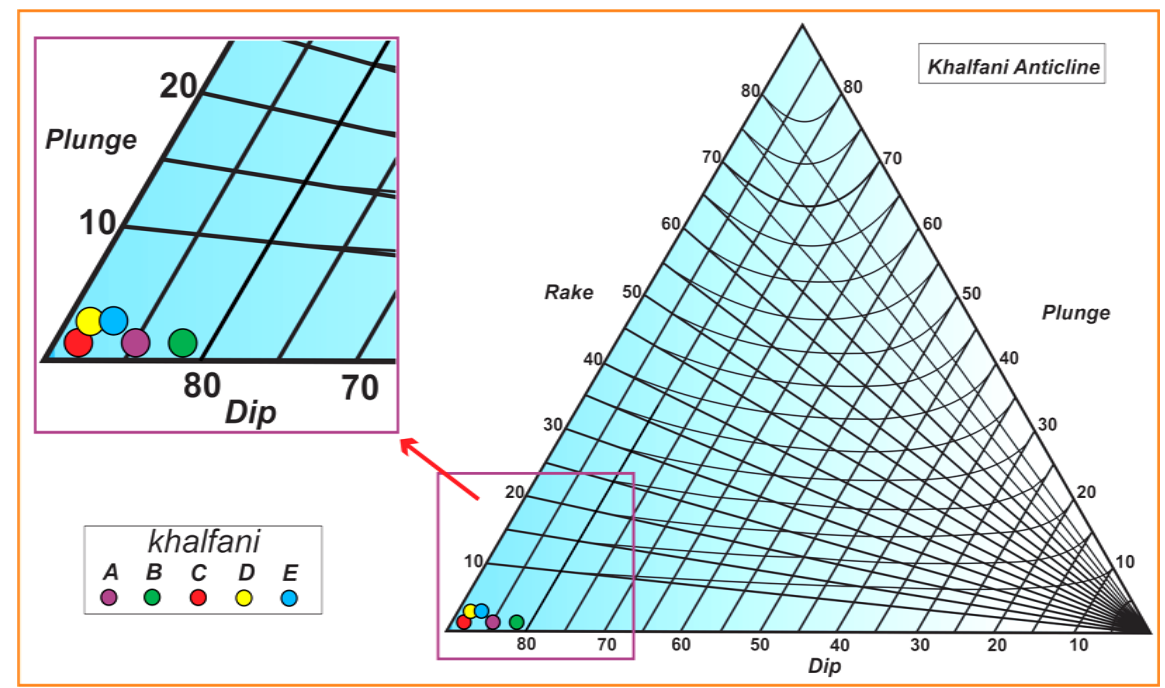

Figure 6. Triangle form diagram shows type of fold in sections of the Khalfani anticline, based on [41].

Based on the classification of Rickard (1971) [41], in all parts of the Khalfani anticline, type of fold is Upright horizontal fold (Figure 6). Based on classification of Ramsay (1967) [40] the orientation of fold in this anticline evaluated, for A-A' to E-E' profiles (Figure 6). Results show the orientation of fold in the Khalfani anticline is same together and type fold is upright sub-horizontal. In Figure 7, 3D path profiles show that location of these profiles is match along the cross sections in the study area.

\section{Main Faults in the Study Area}

The Zagros fold-thrust belt (ZFTB), in southwest Iran, exposes extensive areas of deformed Cambrian to Holocene sedimentary rocks with minimum vegetation cover (e.g., [49]-[51]). This Phanerozoic sequence has folded and faulted above the crystalline Precambrian basement, forming large (approximately $104 \mathrm{~m}$ ), doubly plunging asymmetric folds that host vast volumes of hydrocarbons in anticlinal traps. The Zagros fold-thrust belt has main basement faults or active deep-seated faults. Recent work by [52] shows that basement faults such as the Oman, Bastak,Bostaneh, Hendurabi, Razak, Sarvestan, and Kazerun faults mapped by field observation and integration of geomagnetic maps with remotely sensed data, align with some of the domain boundaries, which were delineated in this study based on the fracture analysis, and the regional changes in the fold axial traces. The changes in the axial traces, from the general NW-trending in the Fars region to the EW-trending in Larestan, and toward the Bandar Abbas region, can be explained by the presence of active deep-seated faults [52]. The development of these fault zones in the sedimentary cover, their relation to the inherited and active basement faults and their importance in the hydrocarbon exploration is discussed [50].

The main faults in the study area are the Razak and Hendurabi fault. The Razak fault was first introduced by Barzegar (1994) [31], based on satellite images in southern Iran. This fault has $230 \mathrm{~km}$ long and NNE-SSW trend. This researcher [31] has considered this fault as a basement fault. This researcher is considered the main control factor on the Hormuz salt basin in paleo-environment was the Razak Fault and the activity of this fault belongs to Cambrian to Late Pliocene reports. The Razak fault can be seen as a line structural feature in the geological map of the surface. The Razak fault in the basement is clear with regard to its role in the development of the Gavbandi paleo-high as well as the western border of the salt dome in the Fars area and Zagros fold-thrust belt. In Figure 1, the Razak Fault is clearly visible on the map and its effects. Based on [53] indicates that the Razak fault is a passive fault formed only as a result of variation in the folding style caused by changes in thickness of the folded strata as it moves onto the basement high across this lineament. The main activity along this basement lineament was during the Early Paleozoic.

One of the main faults in the study area is the Hendurabi fault. A few researchers [31]-[52] studied the Hendurabi fault. This fault with Northeast-Southwest introduced as a basement fault based on satellite images interpreted the changes in the geometry and style of deformation. It seems that in the study area, folding style and 


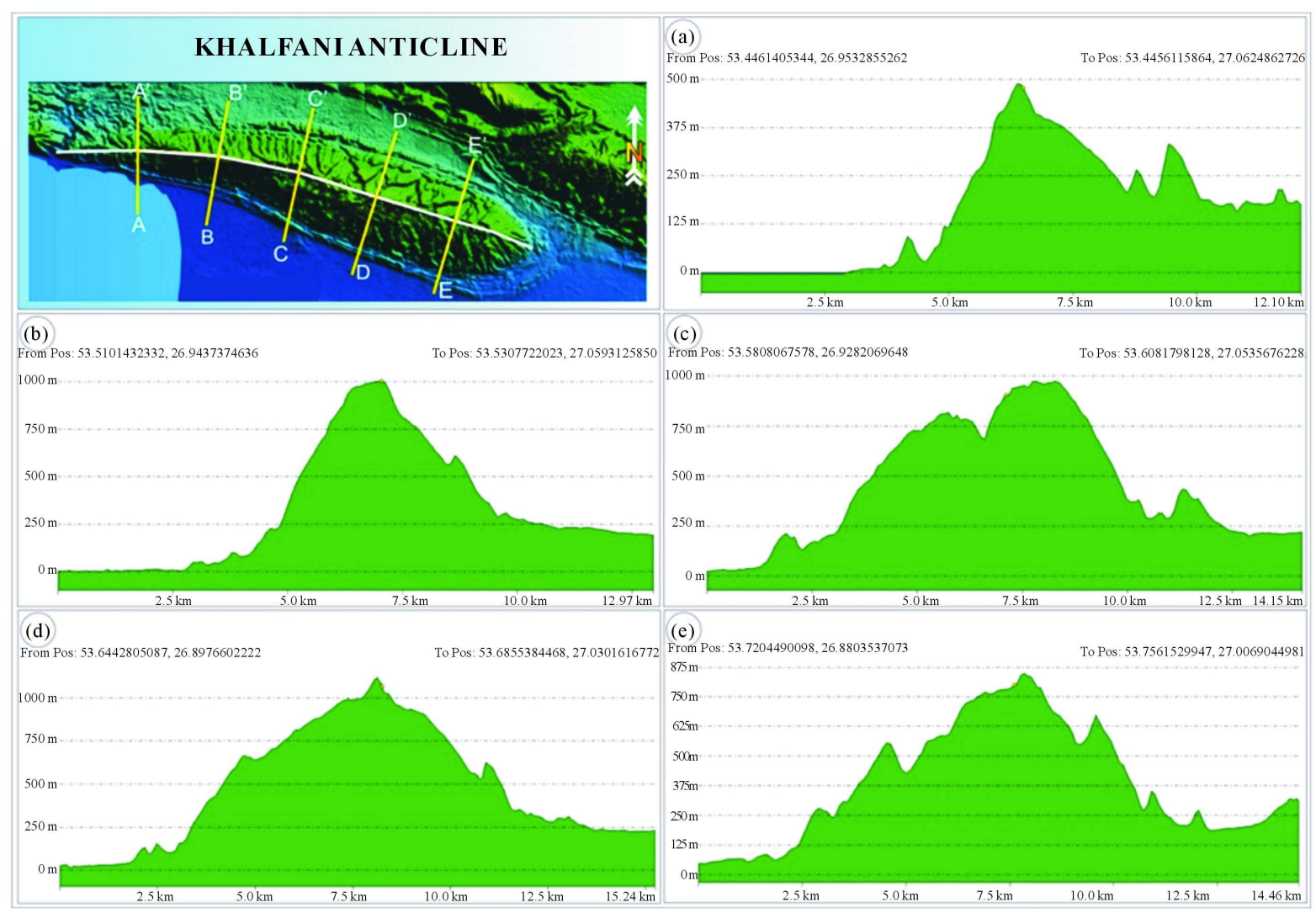

Figure 7. These diagrams showing 3D path profiles of the Khalfani anticline (location of these profiles is located along the cross sections A-A' to E-E'.

variation of structural style created affect by the Razak and the Hendurabi sinistral strike slip fault. On the other hand, fold, with close sideways require special attention as structural view and this type fold can be indicated more deformation created by main faults in the study area.

\section{Conclusions}

In the study area, based on classifications of fold in different methods, fold style is same together. Fold, with close sideways requires special attention as structural view; then the Khalfani anticline with close style in all parts has special deformation and folding style. It seems that in the study area, folding style and variation of structural style have been created by effect of the Razak and the Hendurabi sinistral strike slip fault. Because these faults are basement or deep-seated faults, special folding style and special deformation can be formed in the study area. In addition, the Khalfani anticline in the study area has restricted within the Razak and the Hendurabi sinistral strike slip faults.

Based on gave results, the axial planes in all parts of the Khalfani anticline are sub-horizontal with 82 - 88 degree in different parts. According to these results, the Khalfani anticline in the study area has young folding history. On the other hand, type fold in all parts of this anticline is close type. This case can show the activity of the Razak and the Hendurabi sinistral strike slip faults affected on the structural style of the Khalfani anticline. Finally the Khalfani anticline has suffered more deformation affected by the activity of main faults in the study area.

\section{Acknowledgements}

The authors acknowledge the Department of geology, Islamic Azad University, Science and Research branch, Tehran, Iran for funded this project. In addition, we thank Vice-President for Research in Science and Research branch, Tehran. 


\section{References}

[1] Koop, W. and Stoneley, R. (1982) Subsidence History of the Middle East Zagros Basin, Permian to Recent. Philosophical Transactions of the Royal Society A, 305, 149-168. http://dx.doi.org/10.1098/rsta.1982.0031

[2] Beydoun, Z.R., Hughes Clark, M.W. and Stoneley, R. (1992) Petroleum in the Zagros Basin; a Late Tertiary Foreland Basin Overprinted onto the Outer Edge of a Vast Hydrocarbon-Rich Palaeozoic-Mesozoic Passive Margin Shelf. American Association of Petroleum Geologists, Memoir, 55, 309-339.

[3] Alavi, M. (2004) Regional Stratigraphy of the Zagros Fold-Thrust Belt of Iran and Its Proforeland Evolution. American Journal of Sciafence, 304, 1-20. http://dx.doi.org/10.2475/ajs.304.1.1

[4] Wells, A.J. (1969) The Crush Zone of the Iranian Zagros Mountains and Its Implications. Geological Magazine, 106, 385-394. http://dx.doi.org/10.1017/S0016756800058787

[5] Falcon, N. (1974) Southern Iran: Zagros Mountains. In: Spencer, A., Ed., Mesozoic-Cenozoic Orogenic Belts, Geological Society of London, Special Publication 4, London, 199-211. http://dx.doi.org/10.1144/GSL.SP.2005.004.01.11

[6] Haynes, S.J. and McQuillan, H. (1974) Evolution of the Zagros Suture Zone, Southern Iran. Geological Society of America Bulletin, 85, 739-744. http://dx.doi.org/10.1130/0016-7606(1974)85<739:EOTZSZ>2.0.CO;2

[7] Sepehr, M. and Cosgrove, J.W. (2004) Structural Framework of the Zagros Foldthrust Belt, Iran. Marine and Petroleum Geology, 21, 829-843. http://dx.doi.org/10.1016/j.marpetgeo.2003.07.006

[8] Mouthereau, F., Lacombe, O. and Meyer, B. (2006) The Zagros Folded Belt (Fars, Iran): Constraints from Topography and Critical Wedge Modelling. Geophysical Journal International, 165, 336-356. http://dx.doi.org/10.1111/j.1365-246X.2006.02855.x

[9] Molnar, M. (2006) Tertiary Development of the Zagros Mountains. Geol 418-Earth History.

[10] Furst, M. (1976) Tektonik und Diapirismus der östlichen Zagros ketten. Zeitschrift der Deutschen Geologischen Gesellschaft, 127, 183-225.

[11] Sella, G.F., Dixon, T.H. and Mao, A. (2002) REVEL: A Model for Recent Plate Velocities from Space Geodesy. Journal of Geophysical Research, 107, 2081-2110. http://dx.doi.org/10.1029/2000JB000033

[12] Tatar, M., Hatzfeld, D., Martinod, J., Walpersdorf, A., Ghafori-Ashtiany, M. and Chéry, J. (2002) The Present-Day Deformation of the Central Zagros (Iran) from GPS Measurements. Geophysical Research Letters, 29, 1927-1930. http://dx.doi.org/10.1029/2002GL015427

[13] Vernant, P., Nilforoushan, F., Hatzfeld, D., Abbassi, M.R., Vigny, F., Masson, F., Nankali, H., Martinod, J., Ashtiani, A., Bayer, R., Tavakoli, F. and Chery, J. (2004) Present-Day Crustal Deformation and Plate Kinematics in the Middle East Constrained by GPS Measurements in Iran and Northern Oman. Geophysical Journal International, 157, 381-398. http://dx.doi.org/10.1111/j.1365-246X.2004.02222.x

[14] Walpersdorf, A., Hatzfeld, D., et al. (2006) Difference in GPS Deformation Pattern of North and Central Zagros (Iran). Geophysical Journal International, 167, 1077-1088. http://dx.doi.org/10.1111/j.1365-246X.2006.03147.x

[15] Motiei, H. (1993) Stratigraphy of Zagros. Treatise on the Geology of Iran. Ministry of Mines and Metals, Geological Survey of Iran, Tehran.

[16] Molnar, M. (2006) Tertiary Development of the Zagros Mountains, Geol 418-Earth History.

[17] Blance, E.J.P., et al. (2003) Structural Styles in the Zagros Simple Folded Zone, Iran. Journal of the Geological Society, 160, 401-412. http://dx.doi.org/10.1144/0016-764902-110

[18] Burberry, C.M., Cosgrove, J.W. and Liu, J.-G. (2008) Spatial Arrangement of Fold Types in the Zagros Simply Folded Belt, Iran, Indicated by Landform Morphology and Drainage Pattern Characteristics. Journal of Maps, 4, 417-430. http://dx.doi.org/10.4113/jom.2008.97

[19] Alavi, M. (2004) Regional Stratigraphy of the Zagros Fold-Thrust Belt of Iran and Its Proforeland Evolution. American Journal of Science, 304, 1-20. http://dx.doi.org/10.2475/ajs.304.1.1

[20] Bahroudi, A. and Koyi, H. (2003) Effect of Ductile and Frictional Décollements on Style of Extension. Journal of Structural Geology, 25, 1401-1423. http://dx.doi.org/10.1016/S0191-8141(02)00201-8

[21] Falcon, N. (1974) Southern Iran: Zagros Mountains. In: Spencer, A., Ed., Mesozoic-Cenozoic Orogenic Belts, Geological Society, London, 199-211. http://dx.doi.org/10.1144/gsl.sp.2005.004.01.11

[22] Setchell, C.M., Cosgrove, J.W. and Liu, J.-G. (2007) The Distribution of Fold Types in the Zagros Simply Folded Belt, Iran. Imperial College, London, (Map Scale 1:100,000).

[23] Sherkati, S. and Letouzey, J. (2004) Variation of Structural Style and Basin Evolution in the Central Zagros (Izeh Zone and Dezful Embayment), Iran. Marine and Petroleum Geology, 21, 535-554. http://dx.doi.org/10.1016/j.marpetgeo.2004.01.007

[24] Sherkati, S., Molinaro, M., Frizon de Lamotte, D. and Lettouzey, J. (2005) Detachment Folding in the Central Eastern 
Zagros Fold-Belt (Iran): Salt Mobility, Multiple Detachments and Late Basement Control. Journal of Structural Geology, 27, 1680-1696. http://dx.doi.org/10.1016/j.jsg.2005.05.010

[25] Maleki, Z., Arian, M., Solgi, A. and Ganjavian, M.A. (2014) The Elements of Fold Style Analysis in the Khaftar Anticline, Zagros, Iran. Open Journal of Geology, 4, 79-92. http://dx.doi.org/10.4236/ojg.2014.43008

[26] Maleki, Z., Arian, M. and Solgi, A. (2014) Structural Style and Hydrocarbon Trap of Karbasi Anticline, in the Interior Fars Region, Zagros, Iran. Solid Earth, 6, 2143-2167. http://dx.doi.org/10.5194/sed-6-2143-2014

[27] Maleki, Z., Arian, M., Solgi, A. and Ganjavian, M.A. (2013) Sediment Deformations on Strike Slip Fault Blocks and Analogue Modeling: A Case Study of Nezamabad Fault, Interior Fars, Zagros. Journal of Sciences (Islamic Azad University), 89, 39-51. (In Persian)

[28] Arian, M. and Maleki, Z. (2014) Principals of Experimental Tectonics. Asar Nafis Publication, Qum, 224 p.

[29] Letouzey, J. and Sherkati, S. (2004) Salt Movement, Tectonic Events, and Structural Style in the Central Zagros Fold and Thrust Belt (Iran). Proceedings of the 24th Annual Gulf Coast Section SEPM Foundation, Interactions and Bob F. Perkins Research Conference on Salt Sediments Hydrocarbon Prospectivity, Houston, 5-8 December 2004, 535-554.

[30] Maleki, Z., Arian, M. and Solgi, A. (2015) Folding Pattern in the Fars Province, Zagros Folded Belt: Case Study on the Karbasi and Khaftar Anticlines, Interior Fars, Iran. Solid Earth Discussions, 7, 2347-2379. http://dx.doi.org/10.5194/sed-7-2347-2015

[31] Barzegar, F. (1994) Basement Fault Mapping of Zagros Folded Belt (S. W. Iran) Based on Space-Born Remotely Sensed Data. Proceeding of the 10th Thematic Conference on Geologic Remote Sensing: Exploration, Environment and Engineering, San Antonio, 9-12 May 1994, 455-466.

[32] Maleki, Z. and Jahadgar, F. (2015) Folding Style of the Kuh-e Siah Anticline in the Sarvestan Area, Interior Fars, Zagros, Iran. Open Journal of Geology, 5, 552-561. http://dx.doi.org/10.4236/ojg.2015.58050

[33] Maleki, Z. (2015) The Unique Folding Style in the Zagros Simply Folded Belt, the Kuh-e Qazi Anticline, South Iran. Open Journal of Geology, 5, 514-526. http://dx.doi.org/10.4236/ojg.2015.57047

[34] O’Brien, C.A.E. (1950) Tectonic Problems of the Oil Field Belt of Southwest Iran. Proceedings of the 18th International of Geological Congress, Part 6, Great Britain, 45-58.

[35] Davis, D. and Engelder, T. (1985) The Role of Salt in Fold-and-Thrust Belts. Tectonophysics, 119, 67-88. http://dx.doi.org/10.1016/0040-1951(85)90033-2

[36] Arian, M. (2013) Physiographic-Tectonic Zoning of Iran’s Sedimentary Basins. Open Journal of Geology, 3, $169-177$. http://dx.doi.org/10.4236/ojg.2013.33020

[37] Leturmy, P. and Robin, C. (2010) Tectonic and Stratigraphic Evolution of Zagros and Makran during the MesozoicCenozoic. The Geological Society, London, 367 p.

[38] Bordenave, M.L. and Huc, A.Y. (1995) The Cretaceous Source Rock in the Zagros Foothills of Iran: An Example of a Large Size Intracratonic Basin. Revue de L, institute Francais du petrole, 50, 727-753. http://dx.doi.org/10.2516/ogst:1995044

[39] Twiss, R.J. and Moores, E.M. (1992) Structural Geology. W.H. Freeman and Company, New York, 532.

[40] Ramsay, J.G. (1967) Folding and Fracturing of Rocks. McGraw-Hill, New York, 568.

[41] Rickard, M.J.A. (1971) Classification Diagram for Fold Orientation. Geological Magazine, 108, 23-26. http://dx.doi.org/10.1017/S0016756800050925

[42] Ragan, D.M. (1985) Structural Geology, an Introduction to Geometrical Techniques. Third Edition, John Wiley \& Sons, Inc., New York, 210-215.

[43] Molnar, M. (2006) Tertiary Development of the Zagros Mountains. Geol 418—Earth History.

[44] Colman-Sadd, S.P. (1978) Fold Development in Zagros Simply Folded Belt, Southwest Iran. Bulletin of the American Association of Petroleum Geologists, 62, 984-1003. http://dx.doi.org/10.1306/c1ea4f81-16c9-11d7-8645000102c1865d

[45] Nogole-Sadat, M.A.A. and Almasian, M. (1993) Tectonic Map of Iran, Scale 1:1000, 000. Geological Survey of Iran, Tehran.

[46] Furst, M. (1990) Strike-Slip Faults and Diapirism of the South-Eastern Zagros Ranges. Proceeding of Symposium on Diapirism, 2, 149-182.

[47] Ala, M.A. (1974) Salt Diapirism in Southern Iran. AAPG Bulletin, 58, 1758-1770.

[48] Player, R.A. (1969) The Hormuz Salt Plugs of Southern Iran. PhD Thesis, Reading University, Reading, 300.

[49] Sepehr, M. and Cosgrove, J.W. (2005) Role of the Kazerun Fault in the Formation and Deformation of the Zagros Fold-Thrust Belt, Iran. Tectonics, 24, 1-13. http://dx.doi.org/10.1029/2004TC001725

[50] Sepehr, M., Mirhashemi, S.F. and Yavari, M. (2009) Origin of Transfer Faults in the Fars Folded Belt, Zagros Moun- 
tains. Proceedings of the 1st EAGE International Petroleum Conference and Exhibition Session: Structural Geology and Salt Tectonics I, Shiraz, 4 May 2009.

[51] Mobasher, K. (2007) Kinematic and Tectonic Significance of the Fold- and Fault-Related Fracture Systems in the Zagros Mountains, Southern Iran. Georgia State University, Atlanta, 144 p.

[52] Yassaghi, A. (2006) Integration of Landsat Image Interpretation and Geomagnetic Data on Verification of Deep-Seated Transverse Fault Lineaments in SE Zagros, Iran. International Journal of Remote Sensing, 27, 4529-4544. http://dx.doi.org/10.1080/01431160600661283

[53] Motamedi, H., Sherkati, S. and Sepehr, M. (2012) Structural Style Variation and Its Impact on Hydrocarbon Traps in Central Fars, Southern Zagros Folded Belt, Iran. Journal of Structural Geology, 37, 124-133. http://dx.doi.org/10.1016/j.jsg.2012.01.021 